横浜市における米軍接収地の変化に関する研究

\title{
On The Release of Requisition Land in Yokohama City
}

横山、裕*2 谷地 由江*3 岸井 隆幸*4 By Hiroshi YOKOYAMA, Yoshie YACHI and Takayuki KISHII

\section{1.はじめに}

横浜市は第 2 次世界大戦以前から港湾、重化学工 業、住機能で大きな役割を担っていた都市であった が、戦災に遭い、さらに接収により戦災復興が遅れ ていくこととなったといわれている。1) 事実、横浜 地区での接収は、全国接収土地面積の $62.3 \%$ 占め、 横浜市中心部である中区の接収地面積の割合は 23.3\%にも及び、港湾施設の $90 \%$ も接収されていた。 また、現在でも図 1 のように横浜市は市域面積の $1.2 \%$ （約 526ha）を接収されており、今後も大規模 接収地、解除交涉・跡地利用問題を抱えている。

こうした戦後の軍用財産・米軍占有地を扱った論 文としては昌子他 ${ }^{2)}$ があり、昌子は横須賀市転換事 業による転用の実績を取り扱い、跡地利用計画と周 辺の環境整備とをどう連携させるかを指摘した。し かし、旧軍用財産よりも民有地・公共用地の接収割 合の大きい横浜市を扱っている研究はまだない。大和市 そこで本研究では、研究対象を横浜市とし、接収地 の変化と戦㷋復興事業との関連、接収解除後の土地 利用について調査・分析を行った。

本稿では(1)横浜市内接収地の解除経緯、(2)接収地 面積の変遷と各区毎の特徴の分析、(3)接収解除跡地 の利用傾向の分析の順に論じていくこととする。

研究方法としては、横浜市発行の「市政概要」(昭 和 27 年〜平成 8 年)、「横浜市内米軍接収地の現況 と接収解除対策」(昭和 39 年)、「港町横浜の都市形 成史」(昭和 56 年)、「横浜の 20 のまち」(昭和 61 年)、「横浜市と米軍基地」(平成 8 年)、建設省発行

*1キーワーズ : 土木史, 接収地, 横浜 $* 2, * 3$ 学生員 日本大学大学院博士課程前期土木工学専攻 （東京都千代田区神田駿河台 1-8, TEL\&FAX 03-3259-0671) *4 正員 日本大学理工学部土木工学科教授 （東京都千代田区神田駿河台 1-8, TEL\&FAX 03-3259-0671）
の「戦災復興誌」(昭和 36 年) 等の資料を使って、 接収地面積の時間的変遷と土地利用変化・関連事業 の状況学考察する。

\section{2. 横浜市の接収地をめぐる社会の動向}

\section{(1)全国の接収解除状況}

表 1 は全国調達局管内接収土地面積の比較である。 全国調達局は民間の土地を接収するときに手続きを

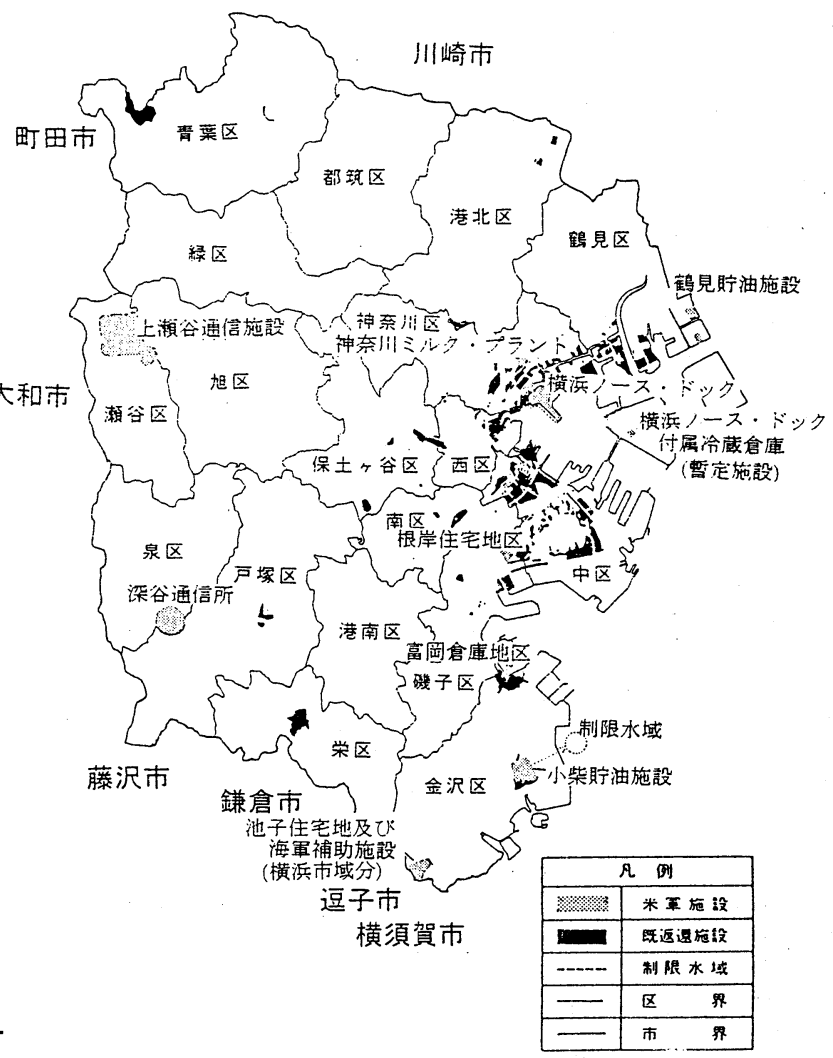

図 1 横浜市市域と接収地 ${ }^{3)}$ 
表 1 全国調達局管内別接収地比較 ${ }^{4)}$

\begin{tabular}{|c|c|c|c|c|c|c|}
\hline & \multicolumn{2}{|c|}{ 昭和6年10月1日 } & \multicolumn{4}{|c|}{ 昭和33年11月1日 } \\
\hline $\begin{array}{l}\text { 地区 } \\
\text { (局) 別 }\end{array}$ & $\begin{array}{l}\text { 土地接㣔 } \\
\text { 面積 (埇) }\end{array}$ & 㴆 & $\begin{array}{l}\text { 土地接収 } \\
\text { 面积 (坪) }\end{array}$ & 㐮 & $\begin{array}{l}\text { 一時使用 } \\
\text { 面秷 (坪) }\end{array}$ & $\begin{array}{l}\text { 䌚絸使用 } \\
\text { 面棈 (坪) }\end{array}$ \\
\hline 横浜 & $69,081.733$ & 62. $27 x$ & $30,291,479$ & $58.57 \%$ & 306,220 & $29.985,259$ \\
\hline 東京 & $2,490,594$ & 2. $24 k$ & 3. 541,648 & $6.85 \%$ & 1. 107.551 & 2. 434.097 \\
\hline 大阪 & 680.153 & $0.61 \%$ & 95.558 & $0.18 x$ & & 95.558 \\
\hline 名古屋 & 370,714 & $0.33 \%$ & 43. 074 & $0.08 x$ & & 43.074 \\
\hline 题 & 270.670 & $0.24 \%$ & 121.479 & $0.23 x$ & 1.004 & 120.475 \\
\hline 楅周 & 5.494 .129 & 4. $95 \%$ & 1.959 .349 & 3. $79 x$ & & $1.959,349$ \\
\hline 仙台 & $9,827.245$ & $8.86 \%$ & $1,073.281$ & $2.08 \%$ & & $1,073,281$ \\
\hline 札显 & 22. 731.693 & 20. $49 \%$ & $14,594,094$ & $28.22 \%$ & & 14.594 .094 \\
\hline 㝇 & 110.946 .931 & $100.00 \%$ & 51.719 .962 & $100.00 \%$ & 1. 414.775 & $50,305,187$ \\
\hline iit) & $D^{\prime}=$ & -1 & 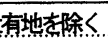 & & & \\
\hline
\end{tabular}

行うのでこの表の中に国有地は入っていない。この 表は沖縄を除く日本の都道府県を 8 つ局に区分し て接収地面積を昭和 26 年と昭和 33 年の 2 時点で 比較している。ここで横浜地区とは神奈川・静岡・ 山梨の 3 県、東京地区とは東京・千葉・埼玉 ・群馬 ・ 杤木・茨城の 1 都 5 県を管轄している。これをみて も横浜地区の接収地の割合は高いことがわかる。接 収土地面積は半分に減っているが、全国に占める割 合は殆ど差がないのがわかる。また東京地区と横浜 地区を昭和 33 年の時点で比較すると横浜地区の方 が、継続使用面積が圧倒的に多いのがわかる。

(2)横浜市の接収解除経緯

昭和 20 年 8 月、連合軍の占領と同時に横浜市の 接収の歴史は幕を開けた。横浜の経済において絶対 必要不可欠である港湾施設は大栈橋・山下埠頭・大 黒埠頭なども含め、約 $90 \%$ が接収された。また、横 浜市内の土地も関内・関外地区など戦前までの商 業・行政の中心部が接収されていった。

昭和 25 年には朝鮮戦争が勃発して、米軍の韓国 援助の兵器輸送基地として再び横浜港が重視される。 この時期の特需景気による日本経済の立ち直りの陰 で、横浜市は接収延期の可能性が高まり、経済活動 は停滞していく。その後も市内では連合軍の占領地 政策・米軍駐留情勢により、接収・接収解除・再接 収を繰り返した。これにより接収面積・接収解除率 は絶えず変動することになる。昭和 26 年 4 月にサ ンフランシスコ講和条約と日米安全保障条約が締結 されて、翌年の昭和 27 年 2 月に東京で署名された 行政協定に基づき昭和 27 年 7 月に「在日米軍に提 供する施設及び区域に関する協定」(以降、行政協定 と記す）が締結された。この協定が告示されたこと
により市内の接収区域が確認され、連合軍の利用し ていない土地を随時返還していくことになった。

一方で地方自治体側の動きとして、昭和 26 年 8 月に横浜市・神奈川県庁・横浜商工会議所が一大接 収解除運動を展開するために、横浜復興建設会議を 設立し接収解除運動を展開した。昭和 32 年 2 月に は横浜市の戦後初めての総合計画「横浜国際港都建 設総合基本計画」が発表された。この中でも経済発 展の必要条件として、接収解除が最優先課題として 取り上げられている。

昭和 35 年に新日米安全保障条約が発効されて、 米軍基地の固定化現象が生じ、接収解除はゆっくり と進んだ。

昭和 21 年から昭和 34 年にかけて横浜市の戦災復 興計画は、接収による物理的な制約と経済回復の遅 れ、市財政の悪化等により大幅に縮小される。また 接収により商業、業務的機能の市外流出が続いた。 昭和 36 年 3 月には市議会に接収解除促進実行委員 会 (昭和 60 年 5 月に接収解除促進特別委員会に改 組）が設置された。昭和 38 年 7 月に横浜市は接収 解除事務を市政の重要事項として取り上げ、総務局 涉外部を設置して接収解除に努力することになる。

現在横浜市で行われている総合計画「ゆめはま 2010 プラン」においても接収解除跡地利用構想を揭 げて、政府及び米軍に対して、横浜市・市議会・市 民が一体となり接収地の早期全面返還を求めている。

\section{3. 接収地の変遷}

（1）横浜市における接収と接収解除の概要

図 2 は横浜市の接収面積・解除面積 ・土地接収解 除率をあらわしている。6)

接収面積の変化を見ると、昭和 30 年までにほと んど接収が進んでいたことがわかる。接収解除は昭 . 和 30 年代半ばまでに急速に進み、その後はゆっく りと行われている。接収解除率は昭和 25 年まで右 肩上がりに進んでいたが、朝鮮戦争の影響があり、 昭和 26 年には $22 \%$ から $19 \%$ にがっている。この ほかにも昭和 44 年・49 年にもわずかながら接収解 除率が下がり、その後昭和 56 年に進んだが、大き な変化とは言えない。このことから近年の接収解除 運動は顕著な結果を残すことなく現在に至っている 


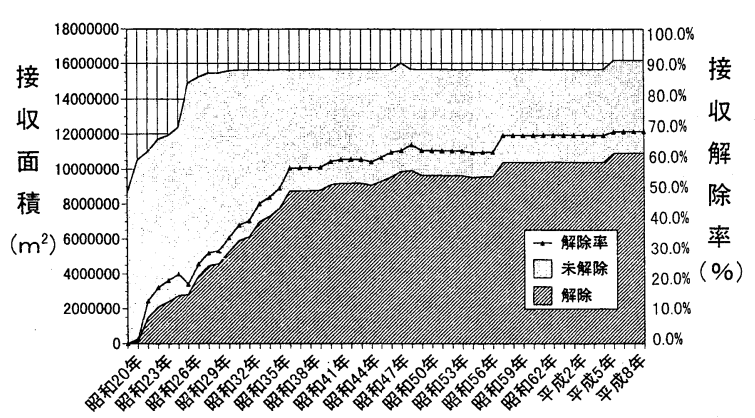

図 2 接収面積 - 解除面積 - 解除率

ことが伺える。

\section{（2）接収地面積の変遷}

図 3 は昭和 20 年から昭和 34 年までの横浜市の各 区別接収土地面積を示している。7)昭和 20 年代前半 は中区・神奈川区・金沢区等臨海部の区に接収地が 多い。これは港湾施設・臨海部工場地域が接収され たことによる。昭和 26 年に戸塚区が大きく接収さ れているのは、この年に上瀬谷通信基地（約 73 万 坪）が接収されているから（昭和 44 年より瀬谷区） である。この為、深谷通信所と上瀬谷通信施設をか
かえる戸塚区の接収面積は中区の接収面積を上回る こととなった。昭和 30 年代前半には中区が減少し、 戸塚区・港北区等内陸部の区で引き続き接収が行わ れている。また、この時期の中区においては、関内・ 山下町などの臨海部の地域の接収地が解除され、山 手・本牧などの兵員住宅として利用した地域の接収 面積が大きくなっている。このことからも事務所・ 埠頭など港湾施設から、内陸郊外部の通信施設・弾 薬庫または住宅などの基地施設へと接収地の利用内 容が変化してきたということがいえる。なお横浜市 は占領軍駐留の中心地ではあったが、米軍基地政策 においては中心地ではなく、昭和 30. 年代に入って からの横浜市の接収地は横須賀・厚木などの主要基 地の予備施設として位置づけられていると言えるで あるう。

（3）各区毎の接収解除地の特徵

図 4 は昭和 20 年〜 34 年まで、各区毎の接収解除 面積の累計をグラフ化したものである。7）このグ ラフから次の(1)～(5)のような傾向を読みとることが できる。(1)〜 (5)は図4 中の番号にも対応している。 尚、表 2 から表 6 は当該時期に接収が解除された具

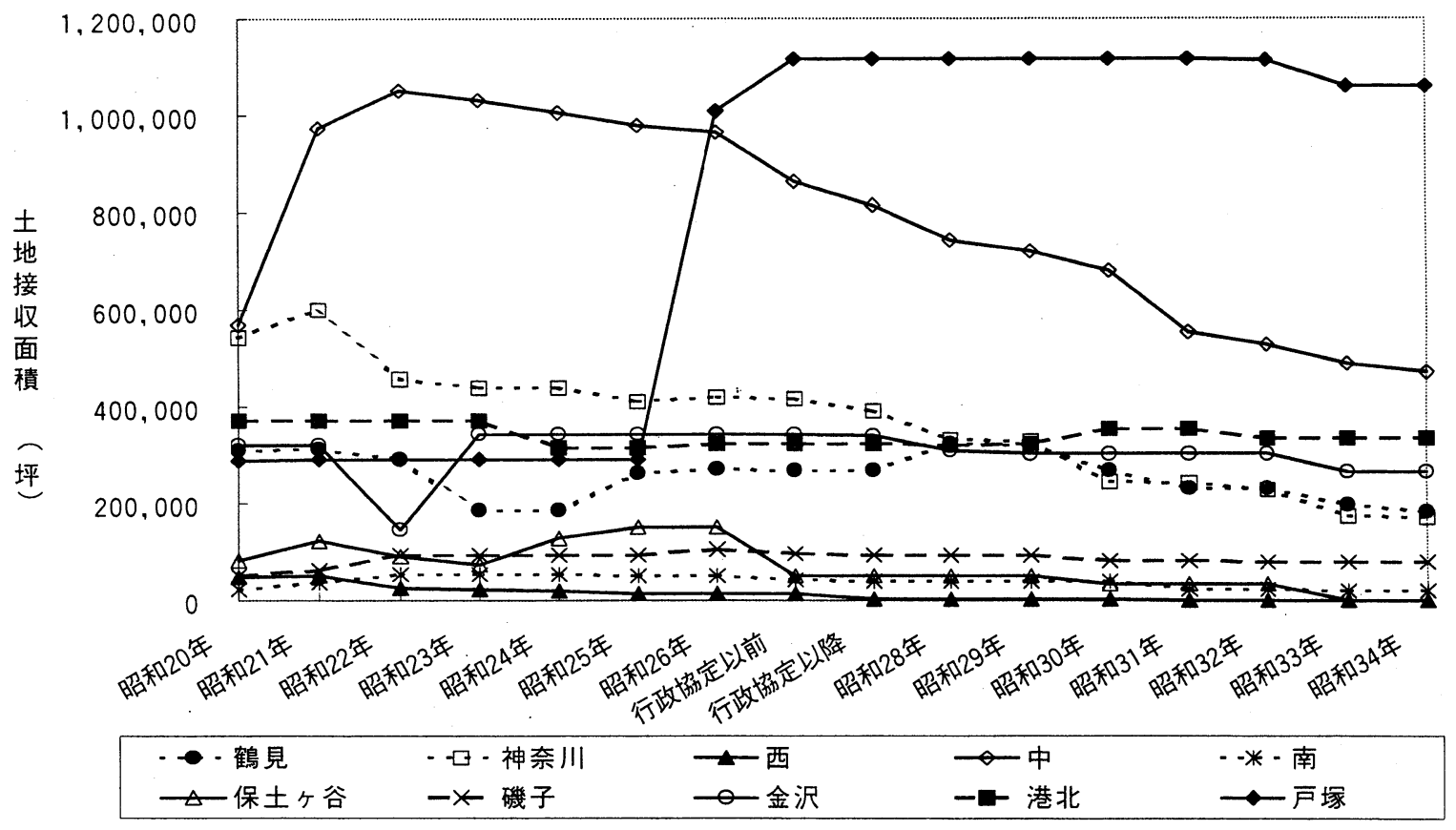

図3 横浜市各区年度別接収土地面積 


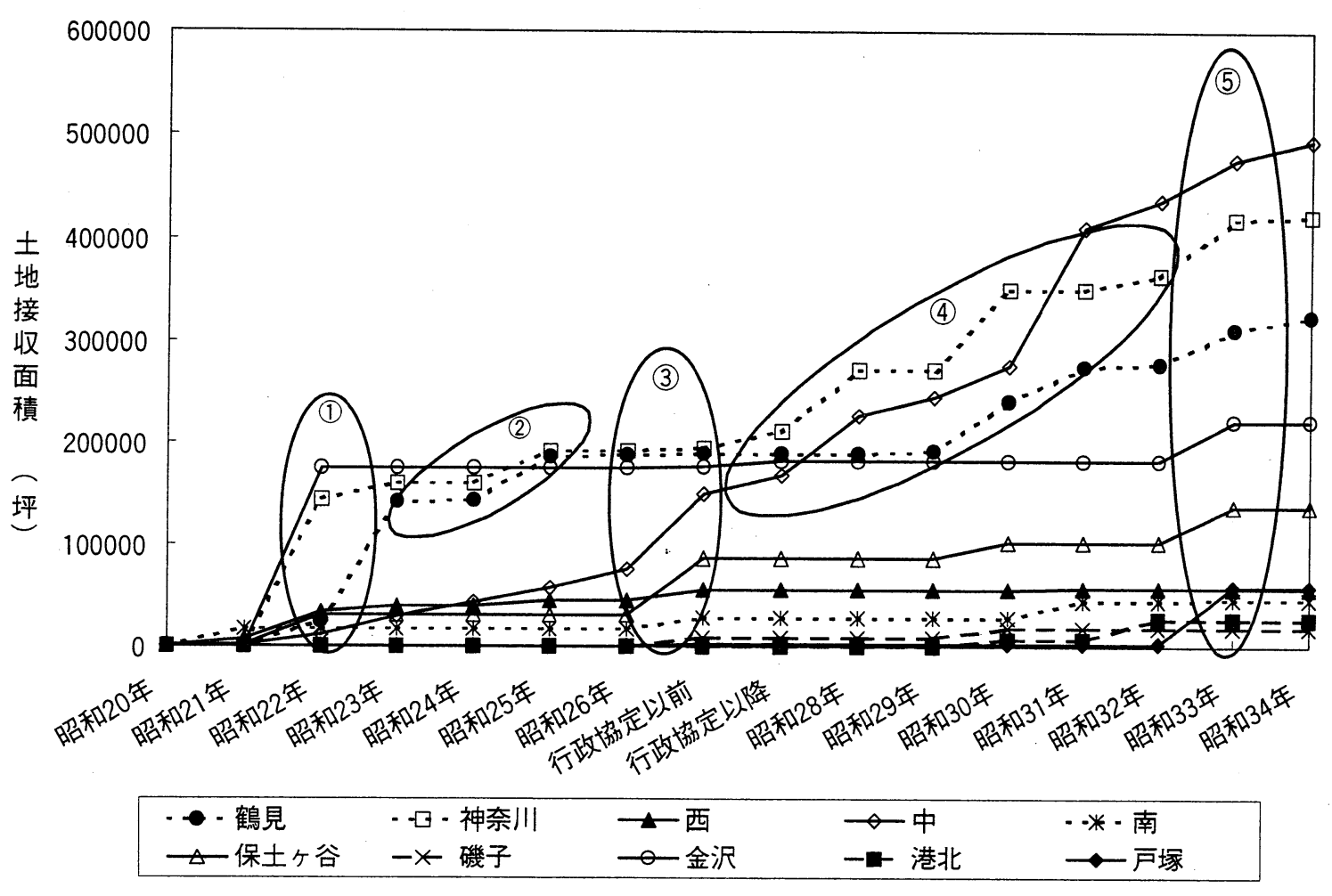

図4 横浜市各区接収解除土地面積

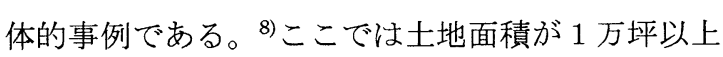
のものをとり上げている。

(1)昭和 22 年に神奈川区・金沢区で多数の接収解 除が進んでいる。金沢区は富岡町にある大日本兵器 という会社の土地が 17 万坪もあった。接収当時

は海岸線の土地を接収していたが、戦後、金沢区の 埋め立てが急速に進み、現在では海岸線より $1 \mathrm{~km}$ も内陸側にある。神奈川区においては、神奈川区出 田町は臨海部の埠頭であり、現在も青果市場として 青果の積み卸しが行われている。浦島丘は県営住宅 が建てられている。その他の地域は現在の $\mathrm{R}$ 東神 奈川駅の西側周辺で反町公園とその近隣部である。

この反町公園は昭和 24 年に日本貿易博覧会の会場 になり、その後は横浜市の仮庁舎として昭和 34 年 まで利用されており、現在では再度公園となってい る。(表 2)

表2 神奈川区の接収解除例.

\begin{tabular}{|c|c|c|c|}
\hline 解除 & 所在 & 所有者 & \\
\hline 7 & 川区出田町 & 浜市 & \\
\hline & -4 & 佐伯萠 & \\
\hline 机2 & 示》 & 吓 & \\
\hline 和 221 & 神奈川区浦島丘 & 神奈川県他 & 21,25 \\
\hline 和 22 & 会川区反 & 佐伯藤之助 & 4 \\
\hline
\end{tabular}

(2)昭和 23 年から 25 年にかけて鶴見区の接収解 除が進んでいる。表 3 の通り、所有者は三菱商事・ 東京ガス・東芝・日本鋼管・石川島タービンと民間 企業の工場用地が多い。解除後の利用は現在も工場 用地で利用されている。

\section{表3 鶴見区の接収解除例}

\begin{tabular}{|c|c|c|c|}
\hline 解除年月日 & 所在地 & 所有者 & 土地( (侔) \\
\hline 昭和 22 年 2 月 24 日 & 鶴見区大黒町 & 三菱商事 & 13,211 \\
\hline 昭和23年11月17日 & 鶴見区未広町 & 東京汃入（株）他2 & 112,292 \\
\hline 昭和 25 年1月 17 日 & 鶴見区末広町 & 東芝 & 14,758 \\
\hline 昭和 25 年 6 月 28 日 & 鶴見区末広町 & 日本鋼管 & 10,643 \\
\hline 昭和 25 年7月 29 日 & 鶴見区末広町 & 石川島タービン & 16,860 \\
\hline
\end{tabular}

(3)昭和 27 年行政協定以前に中区と保土ヶ谷区の 接収解除が進んでいる。これは横浜公園 (一部) と 英連邦墓地が解除されているためであり、解除後も 引き続き公園として利用されている。（表 4)

表4 中・保土ヶ谷区の接収解除例

\begin{tabular}{|c|c|c|c|}
\hline 解除年月日 & 所在地 & 所有者 & 土地 (坪) \\
\hline 昭和 27 年 4 月 8 日 & 中区横浜公園内 & 横浜市 & 16,081 \\
\hline 昭和 27 年 4 月 28 日 & 保土ヶ谷区英連邦墓地 & 横浜市 & 17,206 \\
\hline 昭和 27 年7月 1 日 & 保土ヶ谷区英 & 古平源次郎 & 3.287 \\
\hline
\end{tabular}


(4)行政協定以降には前述の通り全域で解除が進ん でいくことになる。その中でも神奈川区・鶴見区と 中区の接収解除が飛躍的に進んでいる。中区では昭 和 27 年から 30 年にかけては関内・関外地域の商業 地・横浜経済の中心地が、また昭和 30 年から 33 年 にかけては新港町など臨海部の港湾施設がそれぞれ 接収解除されている。（表 5)

\section{表5 中区の接収解除例}

\begin{tabular}{|c|c|c|c|}
\hline 解除年且日 & 所在地 & 所有者 & 土地 $(t$ \\
\hline 沼和27年11月29日 & 中区相生町他 5 町 & 東京銀行他 & 10,644 \\
\hline 昭和 28 年3月31日 & 中区相生町他5町 & 小幡定 & 32,73 \\
\hline 昭和 31 年5月 10 日 & 中区新港町 & 国有 & 19,00 \\
\hline 昭和 31 年 6 月 5 日 & 中区富士見町他 2 町 & 平沼義太郎他 & 12,016 \\
\hline 昭和31年8月6日 & 中区福富町一帯 & 原田重次郎他 & 15,25 \\
\hline 昭和31年8月7日 & 中区新港町 & 関東海運局 & 17,950 \\
\hline 昭和 31 年 8 月 7 日 & 中区新港町 & 関東海運局 & 17.1 \\
\hline 和31年 & 町他 & 川本 & 0 \\
\hline
\end{tabular}

(5)昭和 33 年には中区・神奈川区・鶴見区・金沢 区・保土ヶ谷区・戸塚区で接収解除が一斉に進んで いる。多くの区で民間企業の工場が解除されたこと が表 6 よりうかがえる。また神奈川区は、神奈川通 りは第 1 京浜道路、新子安は第 2 京浜道路とそれぞ れ国道沿いの複数個人所有の私有地が返還されてい る。いずれも返還後には、戦災復興土地区画整理事 業が行われていて現在に至っている。

\section{4. 接収解除跡地の利用傾向}

\section{(1)跡地利用の概要}

接収解除が行われた後の土地利用に関しては、計画 的に開発が行われたものもあれば、権利者に返還
表 6 昭和 33 年の接収解除例

\begin{tabular}{|c|c|c|c|}
\hline 解除年月日 & 所在地 & 所有者 & 土地 (bF) \\
\hline 昭和 33 年2月28日 & 金沢区富岡町 & 且本飛行機价 & 23,195 \\
\hline 昭和33年3月4日 & 神奈川区新子安 & 日本鋼管KK & 10,51 \\
\hline 昭和33年3月26日 & 中区万代，不老田 & 浅井土地 (坪) KK & 14.558 \\
\hline 昭和33年4月8日 & 神奈川区神奈川通 & 滝島泰彦他 & 10,295 \\
\hline 昭和33年4月15日 & 神奈川区新子安 & 荒井文治他 & 24,877 \\
\hline 昭和33年5月12日 & 金沢区富岡町 & 日本飛行機杖 & 16.174 \\
\hline 昭和33年5月16日 & 巨塚区吉田，上倉田 & 日本光学工業KK & 53,916 \\
\hline 昭和33年8月26日 & 保土ヶ谷区川辺田 & 神奈川工業KK & 35,663 \\
\hline 昭和33年10月14日 & 中区根崖町 & 横浜市 & 15,307 \\
\hline 昭和33年11月28日 & 鶴見区大黒町 & 且産 & 17 \\
\hline
\end{tabular}

されただけのものもあるが、程度の差はあるものの 地域周辺の土地利用にも影響を及ぼすと考えられる。 大規模接収地において接収前の状況から接収解除後 の状況への変化を見るために、所有者の分類や解除 後の利用形態を分けることにする。

そこで横浜市の「市勢概要」(昭和 27 年〜平成 8 年）に記されている接収解除地の中から、解除面積 が 10000 坪以上のものを選び、接収前と接収解除後、 所有者が誰であったか、国有・県有・市有の土地は 公有、民有の土地は私有として分類を試みた。

またその土地の所有状況とともにそれが解除後周 辺の整備を伴うことなく利用されたのか（以下単独 と呼ぶ）、周辺の公共施設整備等を伴って利用された のか (以下一体と呼ぶ)、で区分し、しかも公共施設 等の整備が個別に行われたのか、面的に行われたの かで区分した。なお面的整備は開発許可と区画整理 の区分も行った。表 7 はこうした分類で該当する地 区数を示したものである。

全体的な傾向としては、接収前も接収解除後も

\begin{tabular}{|c|c|c|c|c|c|c|c|c|c|c|c|}
\hline & & & & 表7 & 潒地域の分 & 須結果 & & & & & \\
\hline 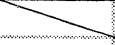 & 手法 & & & & & & & 面的声 & 容備 & & \\
\hline & & & & 行地設季 & & & 等発許的 & & & X画整琽 & \\
\hline 整備方法 & 解除前 & 解除後 & 公有 & 私有 & 公私混在 & 公有 & 私有 & 公私混在 & 公有 & 私有 & 公私混在 \\
\hline 周㲽 & 備等を & 公有 & 8 & 0 & 0 & 1 & 0 & 0 & 0 & 0 & 0 \\
\hline 伴わ & & 私有 & 1 & 0 & 0 & 3 & 21 & 1 & 0 & 0 & 0 \\
\hline & & 公私混在 & 1 & 0 & 0 & 0 & 0 & 0 & 0 & 0 & 0 \\
\hline 周讱の & 禍等を & 公有 & 5 & 0 & 0 & 1 & 0 & 0 & 1 & 0 & 0 \\
\hline 伴 & & 私有 & 0 & 0 & 0 & 1 & 3 & 2 & 0 & 8 & 2 \\
\hline & & 公私混在 & 0 & 0 & 1 & 0 & 0 & 3 & 0 & 0 & 1 \\
\hline
\end{tabular}




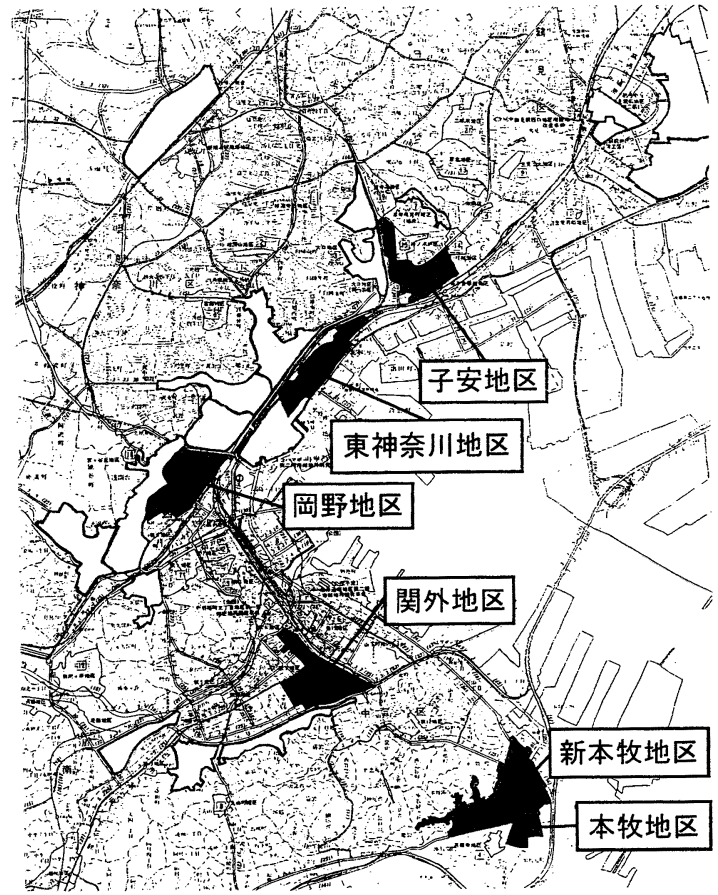

図5 接収関連戦災復興土地区画整理事業9)

所有者形態が変わっていないケースが 64 件中 53 件 と $80 \%$ 以上を占めている。そして公有地が私有地に 変化するケースは全くないということが分かった。 開発分類で見てみると、「単独」の開発許可が 26 件 と最も多く、「一体」の個別施設整備が 6 件と少なく、 それ以外は均等な分布をしていた。分類の中で 地区が多いのは解除前と解除後が私有地で「一体」 の開発許可のケースで 21 件となっている。主に工 業用地で敷地が返還されて、新しく工場が建ってい る事例が見受けられ、鶴見区大黒町など横浜市北部 の臨海地域に多く分布していることが分かった。続 いて解除前と解除後が公有地で「単独」の個別整備 のケースと解除前と解除後が私有地で「一体」の土 地区画整理事業による整備のケースがともに8件と なっている。前者は公共施設の単独整備の事例であ るが、これは主に公園整備があげられる。この場合、 公園用地が接収前から公園緑地として利用されてい た場合が多いが、港北区奈良町のように軍用施設を 返還後に公園緑地に使用している例もある。後者の 場合は当該地区が私有で複数の所有者が存在する場 合が多い。
(2)土地区画整理事業による跡地利用

横浜市は昭和 27 年から岡野地区・関外地区・東 神奈川地区の 3 地区が戦災復興事業の中で接収解除 地整備事業として事業決定された。岡野・東神奈川 の 2 地区は昭和 21 年に土地区画整理の決定告示が なされていたが、接収に阻まれていたので再検討 5 箇年計画の際に保留となっていた。事業決定後も接 収解除は、軍の代替地の決定・施設の整備等が遅れ たために進渉しなかった。10)

岡野地区は現在の横浜駅西口に当たる部分である。 戦後は接収され、資材置き場や石炭置き場になって いたようである。土地区画整理は北幸町と南幸町、 岡野町の 3 町で $51.5 \mathrm{ha}$ からなっていたが、南幸町 の接収解除が遅れたのが原因で接収解除地整備事業 となった。換地処分が完了するのは昭和 41 年にな る。

東神奈川地区は主に現在の JR 東神奈川駅の東側 にあたる。ちょうど第 1 京浜国道（国道 15 号線） に面している部分であり、神奈川区神奈川通（現在 は神奈川区新町）が昭和 33 年に接収解除されてか らの本格的に事業開始したため、換地処分は昭和 51 年と大幅に遅れた。

関外地区は現在の JR 関内駅の西側である。伊勢 佐木町をふくめ横浜市庁舎の近隣地域としてオフィ ス街を形成している地域である。この地域はサンフ ランシスコ講和条約が締結するまで都市計画決定さ れずにいたが、締結後に占領政策の終結、駐留政策 の変化が影響してようやく都市計画決定された。 その後昭和 39 年に $\mathrm{JR}$ 関内駅が供用開始、昭和 40 年代からの横浜市のアメニティ事業などでイセザキ モールができたことは、全国的に有名である。

接収解除地整備事業の他にも接収地を土地区画整 理の区域に含んでいる地域として、本牧地区・子安 地区の 2 地区がある。

本牧地区は本牧町・本牧三之谷・本牧大里町の各 一部、計 13.4ha から形成されているが、本牧町他 10 町の各一部計 $88.2 \mathrm{ha}$ が横浜海浜住宅として接収 されていた。この地区においては接収解除の見通し が立てられず、接収されなかった地域を先に都心地 に対する臨港高級住宅地及び臨港厚生地住宅として 区画整理を始めたものである。昭和 57 年に接収解 除が行われ、接収解除地は新本牧地区土地区画整理 
事業として事業計画決定され、昭和 63 年までの間 に換地処分を完了した。この事業は 21 世紀を展望 した総合的な街づくりを目指し、区画整理事業に見 られた単なる基盤整備に止まらず、建築的な面との 整合をはかりながら良好な都市環境形成を作り出す ことを意図としている。現在でも本牧の顔として観 光地にもなっている。

子安地区は元昭和電工・日本鋼管の社宅敷地であ った横浜兵器廠宿舎 (キャンプサンミギェル) が昭 和 33 年に約 $12 \mathrm{ha}$ を返還された。現在は日本鋼管・ 日本ビクターの工場となっている。この地域も接収 地が JR 新子安駅駅前という主要な位置であったた め、接収解除をしてから本格的な土地区画整理事業 にはいったので、換地処分は昭和 43 年と大幅に遅 れた。11)

\section{(3)公園としての跡地利用}

接収解除跡地は民有地の場合、元の所有者に返還 されるため、従前の土地利用に戻る場合も多いが、 国公有地等については公園として利用されている例 が多い。表 8 は接収解除跡地の公園利用の事例であ る。12)この表から昭和 34 年以前は公園用地を接収 されたものを解除後公園として利用しており、昭和 34 年以降は新しく公園を開園するケースが多い。事 例としてはこどもの国・岸根公園・根岸森林公園が それにあたる。

現在接収されている土地・施設の跡地利用におい ても表 $9^{13)}$ のように $526 \mathrm{ha}$ 中 $454 \mathrm{ha}$ を公園利用・

\section{表9「現在の接収跡地利用構想}

\begin{tabular}{|c|c|c|}
\hline 設 & 跡 地 利 用 構 & \\
\hline 艮 岸 & $\begin{array}{l}\text {-体となった } \\
\text { 整 備 }\end{array}$ & \\
\hline & $\begin{array}{l}\text { 住難場所をかねた } \\
\text { 然園 }\end{array}$ & \\
\hline 奈川ミルクプラント & 益施設建設等 & \\
\hline 庫 地 区 & 都市施設用地 & \\
\hline 小柴貯油施設 & 緑地保全目的の公共公益施設 & \\
\hline 鳥見貯油施設 & 京浜 & \\
\hline 横浜ノースドック & 生活関連物資 & \\
\hline 劲 谷 通 信 所 & & 110,1 \\
\hline 瀬谷通 & & \\
\hline
\end{tabular}

緑地保全に利用しようとしている。

横浜市は現在、総合基幹計画「ゆめはま 2010 プ ラン」を策定しており、その中で市民に豊かな暮ら しを作るという理念を追求している。その中で、緑 のオープンスペースを確保するという項目を設けて いる。 ${ }^{14)}$ 現在の緑地面積は 5943ha であるが、2010 年までには市域面積の約 $20 \%$ にあたる $8840 \mathrm{ha}$ にな るように緑地・公園の整備や保全に力を注いでいる。 横浜市の市民 1 人あたり都市公園面積は $3.26 \mathrm{~m}^{2}$ で政令指定都市 12 都市の中で 2 番目に少なく、市 が描いている接収解除跡地利用構想の中でも、公 園・緑地としての利用計画が約 $75 \%$ と最も多く、 「よこはま 21 世紀プラン」の公園緑地増加計画の 内、約 $15 \%$ を担っていることになる。

表8 主な公園利用の接収解除地

\begin{tabular}{|c|c|c|c|c|}
\hline 接収年月日 & 解除年月日 & 所在地 & 名称 & 接収面樌 (坪) \\
\hline 昭和20年10月15日 & 昭和 27 年 4 月 8 日 & 中区元町 & 元町公園 & 902 \\
\hline 昭和20年9月 25日 & 昭和27年4月10日 & 中区山手町 & 山手公園 & 3,419 \\
\hline 昭和 21 年7月1日 & 昭和 27 年7月 1 日 & 保土ヶ谷区英連邦墓地 & 保土ヶ谷児童遊園地 & 38,114 \\
\hline 昭和20年9月 26日 & 昭和27年9月19日 & 神奈川区 & 神奈川公園 & 4,339 \\
\hline 昭和 20 年10月 13 日 & 昭和 29 年3月31日 & 中区翁町 & 翁町公園 (宿舎) & 392 \\
\hline 昭和 20 年12月1日 & 昭和30年3月24日 & 中区富士見町、山吹町 & 富士見公園 & 301 \\
\hline 昭和25年12月25日 & 昭和 30 年 12 月 15 日 & 保土ヶ谷区花見台 & 花見台公園 & 13,709 \\
\hline 昭和 26 年4月 1 日 & 昭和 30 年 12 月 20 日 & 神奈川区子安台 & 子安台公園 & 8,369 \\
\hline 昭和 26 年1月 27 日 & 昭和 30 年 12 月 21 日 & 磯子区岡村町 & 岡村公園 & 10,257 \\
\hline 昭和26年4月1日 & 昭和 30 年12月22日 & 港北区岸根町 & 岸根公園 & 6,973 \\
\hline 昭和20年12月3日 & 昭和 34 年1月 27 日 & 中区新港町 & 新山下公園 & 5,000 \\
\hline 昭和20年9月2日 & 昭和 35年6月15日 & 中区山下公園 & 山下公園 & 22,461 \\
\hline 昭和20年9月20日 & 昭和 36 年5月5日 & 港北区奈良町 & こどもの国 & 294,471 \\
\hline 昭和20年9月3日 & 昭和44年11月23日 & 中区㝨沢町 & 根岸森林公園 & 50,129 \\
\hline 昭和20年9月2日 & 昭和 46 年 2 月 17 日 & 金沢区富岡町 & 富岡総合公園 & 94,719 \\
\hline 昭和20年9月2日 & 昭和 47 年 10 月 23日 & 鶴見区大黒町 & 大黒町スポーツ広場 & 14,256 \\
\hline 昭和 30 年4月12日 & 昭和 47 年8月 25日 & 港北区岸根町 & 岸根公園 & 22,228 \\
\hline 昭和20年9月25日 & 昭和53年6月19日 & 中区横浜公園 & 横浜公園 & 3,758 \\
\hline 昭和20年9月3日 & 昭和57年3月31日 & 中区・南区・磯子区 & 根岸森林公園 & 15,255 \\
\hline & & & 計 & 114,236 \\
\hline
\end{tabular}


接収地の解除状況と時代背景を考えるとちょうど 昭和 35 年を境にして、前後で 2 種類の傾向がつか めた。前半期は大規模接収のあと順調に接収解除が 進み、後半期は接収解除が伸び悩んでいた。接収地 は全体的に臨海部の港湾施設・中心市街地から内陸 部の通信施設や住宅施設へと変化していった。米軍 が横浜を中心として駐留していた時代から、厚木・ 横須賀等のベースキャンプを中心にしている時代へ の変化が浮き彫りになっていた。

さらに前半期において接収解除は 5 段階に分けら れることができ、神奈川区・鶴見区など横浜市北部 の臨海地域において接収解除が早く行われていた。

接収解除後の跡地利用に関しては、工業地は所有 者にかえって現在もなお工業地になっているが、そ れ以外には区画整理をされたり、公園として利用さ れることが多かった。区画整理の多くは昭和 35 年 以前の戦災復興計画の中で行われ、新本牧のような 新しい街づくりにも活用されている。公園は昭和 35 年以前、公園用地が接収解除されそのまま公園にな るケースが目立ったが、昭和 35 年以降は緑地保全 を目的として公園に利用される例が多く、横浜市の 現公園面積の $15 \%$ を占めている。又、今後接収地の
接収跡地利用構想の中で、約 $75 \%$ が公園に利用され る予定であり、公園緑地の確保を接収地に期待する 割合が大きいことがわかった。

今後の課題としてより詳細なケーススタディを通 じて過去の接収地解除が周辺にもたらした影響を開 発手法別に分析し、今後も予想される大規模土地利 用転換への対応について検討する予定である。

\section{参考文献}

1)「横浜の街づくり」横浜市都市計画局 p. 21 平成 3 年

2）昌子, 金井, 波形 : 横須賀市の都市整備と旧軍用財産の 転用，土木学会第 47 回年次学術講演会 p. $554 \sim$ p. 555 平成 4 年

3）「横浜市と米軍基地」横浜市 $\mathrm{p} 7$ 平成 8 年

4)「横浜市内米軍接収地の現況と接収解除対策」横浜市 p11昭和 39 年より作成

5)「港町横浜の都市形成史」横浜市企画調整局 p. $81 \sim$ p. 91 昭和 56 年

6)「市勢概要」横浜市 昭和 27 年〜平成 8 年 より作成 7)「横浜市内米軍接収地の現況と接収解除対策」横浜市 $\mathrm{p} 40$ 昭 和 39 年より作成

8)「市勢要覧」横浜市 $\mathrm{p} 72 \sim 80$ 昭和 34 年 より作成

9)「横浜の 20 のまち」横浜市 $\mathrm{p} 9$ 昭和 61 年 より作成

10)「戦災復興誌」第一巻 建設省 p. $522 \sim$ p. 523 昭和 36 年

11)「横浜の 20 のまち」横浜市 $\mathrm{p} 40 \sim 104$ 昭和 61 年

12)「横浜市内米軍接収地の現況と接収解除対策」横浜市 $\mathrm{p} 23$ 昭 和 39 年・「市勢概要」横浜市 昭和 27 年〜平成 8 年より作成

13)「横浜市と米軍基地」横浜市 $\mathrm{p} 63$ 平成 8 年

14)「横浜市緑の基本計画素案」横浜市 $\mathrm{p} 38 \sim 39$ 平成 9 年

横浜市における米軍接収地の变化に関する研究

\section{横山 裕 谷地由江 岸井隆幸}

本研究は大規模接收地、跡地利用問題を抱えている横浜市を研究対象とし、接収地の変化と接収解除後 の土地利用について調查・分析を行なったものである。接収地面積の時間的変遷と土地利用変化・関連事業の 状況を考察した。結果、接収解除の傾向としては、前半期順調に接収解除が進んだものの後半期は伸び悩ん でいたこと、接収地は全体的に臨海部の港湾施設・中心市街地から内陸部の通信施設へと変化していること、 接収解除後の跡地利用の傾向は国や市の自治体が使用する場合・工業用地としてもとの所有者が使用寸る 場合・周辺一带を区画整理する場合の 3 種類があることがなどが明らかになった。

\section{On The Release of Requisition Land in Yokohama City}

\section{By Hiroshi YOKOYAMA YoshieYACHI and Takayuki KISHII}

After World War II , a lot of lands in Yokohama City were taken over by the occupation forces. And how we should reuse those lands has been very important issue for Yokohama City Planning. So we researched when and how those requisition lands were released and what happened at those sites after releasing. As a result we indicate that some lands were improved through land readjustment projects and many important parks were born from them. 